\title{
Introduction
}

\section{Betwixt and Between: Refugees and Stateless Persons in Limbo}

\author{
Harry J. Kits
}

$\mathrm{T}$ he refugee experience is far from over upon arrival in a place of asylum. Indeed, in many ways, the struggle to create a new life has only begun. As refugees can attest to, the process of fully normalizing their lives - reuniting with family members, securing local education for themselves and their children, finding appropriate employment, and participating in the political life of their new countries - is one fraught with legal and procedural difficulties, a process that leaves many in "limbo" long after their new lives should be well under way.

Similar limbo is experienced by the stateless, those denied the basic yet essential right of nationality. Like refugees, stateless people face often insurmountable difficulties in securing the core protections of the state in which they reside. And, as is the case for refugees, the existence of international treaties aimed at assuring their protection far from guarantees their physical or legal security.

It was a privilege to be invited to be guest editor of this special of issue of Refuge. Citizens for Public Justice (CPJ) has been involved in Canadian policy related to refugees in limbo for a number of years. Our focus has been to effect policy change - to ensure that the Right of Landing fee (dubbed a head tax) would no longer be charged to Convention refugees, to ensure that Convention refugees and other protected persons can access government loan programs for university, and to propose a policy of automatic landing or permanent residency once a person has been deemed a Convention refugee. Seeking policy change to allow refugees to get on with their lives is often slow, frustrating, and sometimes tedious. But the stories which those in limbo tell — of their flight, of their life today, and of their incredible perseverance - demonstrate the requirement for at least as much perseverance to ensure justice is done.
What has become increasingly clear, as we do this policy work, is the need to understand, compare and contrast Canadian policy and approaches with what is occurring in other countries. Together, all of the authors in this issue of Refuge give us a picture of different kinds of limbo in different parts of the world. Two of the articles also show how statelessness is its own form of limbo. Waiting, betwixt and between, perhaps recognized - but not yet truly accepted - perhaps not even recognized. This is the nature of limbo experienced by refugees and stateless persons the world over.

Included in most of the articles are the voices of persons caught in limbo situations. The expressions of frustration and often painful separations from loved ones make more poignant the reality that policies and practices which cause limbo are not just items for political or academic study; rather, real people are suffering real hardships which need to be alleviated.

For some, limbo begins at the first point of asylum, in a refugee camp. Representative of a situation found in many camps, Awa Abdi's article about 130,000 Somali refugees in camps in Kenya provides a compelling picture of this type of limbo. For well over a decade, these Somali refugees have been able neither to return home nor to move on to a new country of asylum. The emergency need for the camp during a crisis has turned into a semi-permanent limbo situation, with all the familiar consequences of limbo. Inability to procure work, epidemic violence (especially against women), and continuing insecurity leave these refugees in constant dependency on aid from international organizations. It is a picture which often continues as people move beyond these camp situations seeking further asylum.

Distinctive barriers are also faced by stateless persons, who may find themselves without formal status, rights to seek employment, access to health care, or education for 
their children. With neither the right to remain nor anywhere to return to, they are truly betwixt and between. The political determination of statelessness, its distinction from refugee status, and the complexities surrounding this type of limbo are described in the next two articles of this issue.

After a careful review of the unique history of Palestinians who have sought asylum in neighbouring countries such as Egypt, Oroub El Abed argues that Palestinians in Egypt remain stateless until there is a Palestinian State. In limbo in Egypt, Palestinians lack formal UNHCR protection and are not assisted adequately by the United Nations Relief and Works Agency. They have difficulty renewing their residence permit in Egypt, without which they can be deported or imprisoned. Residence permits also give access to travel permits without which travel abroad (or more, re-entry to Egypt) is nearly impossible. Children have no access to free education at any level, and adults have no right to work in the public sector and have restricted rights in the private sector. Rights to ownership are also restricted. The author calls for renewed attention to various UN resolutions, the United Nations Conciliation Commission for Palestine, the 1951 Refugee Convention, and the 1954 and 1961 Conventions on Statelessness for possible durable solutions for these persons in limbo.

Carol Batchelor, of UNHCR, lays out, in depth, the history and interpretation of the 1954 Convention relating to the Status of Stateless Persons and discusses its current implementation within the European Union. The complexity of determining statelessness ("proving a negative") and the inconsistent process for determination of statelessness across EU States cause Batchelor to carefully sort out how the Convention could be interpreted and its implementation harmonized among these European States. Throughout, Batchelor describes how the Convention attempts to promote the acquisition, by stateless persons, of a legal identity and thus legal status as a basis for access to social and economic rights. She systematically reviews how the articles of the Convention can address the limbo situation of recognized stateless persons - issues from residency, to employment, religious freedom, right of association, education, and so on - all typical of the limitations faced by persons in limbo.

Refugees who seek asylum beyond "emergency" camps face, in many countries, indeterminacy and delay at every stage of the process - at the outset, when attempting to gain access to the determination system; once refugee status is granted, while awaiting more permanent residency or equivalent status; and for some, at the tail end of the system, when status is denied, but risks in the country of origin prevent their return home. State-imposed barriers such as security reviews, identity document requirements, and processing fees prolong and exacerbate the challenges of the refugee experience.

The final set of limbo-related articles in this issue documents this aspect of asylum seeking in Britain, Australia, and Canada.

Asylum seekers in Britain, those at the front end who are seeking access to a process to determine their refugee status, are the subject of Anthony Richmond's article. The late 1990s brought increased numbers of asylum seekers, but also increased restrictions. Asylum claims from a specific list of countries were rejected outright as "presumed manifestly unfounded," and there was talk of deporting asylum seekers to "safe havens" on the borders of countries from which they fled. Most recently, proposed legislation would reduce access to an appeal of decisions, and factors such as lack of documentation, travel through a safe third country, and delay in applying would reduce the credibility of a claim. In addition, deterrent measures such as reduced welfare benefits, detentions, and dispersion across the country have been introduced, including a controversial attempt to deny benefits to anyone seeking asylum "incountry." Richmond concludes that barriers such as Britain imposes on asylum seekers, tellingly similar to those in other countries, create more refugees in limbo, as they search for a safe haven somewhere in the world.

Louise Humpage and Greg Marston tackle Australia's temporary protection visa. They describe the situation in Australia, all too typical for those seeking asylum, as distinguishing

between "good" refugees and "bad" refugees. The former are selected overseas, usually after referral from the United Nations High Commissioner for Refugees, and enter Australia with a visa that entitles them to permanent residency (and to apply for citizenship after the prescribed waiting period). "Bad" refugees, on the other hand, are asylum seekers arriving in Australia by boat without "authorization"; that is, a visa and/or a valid passport.

The latter are determined to be refugees, but are not given permanent protection and are left in limbo. What is insightful about this article is its theoretical discussion of the impact of public rhetoric and the sense of belonging for those in limbo. The stigma of a "temporary" protection visa, the article argues, requires a more sophisticated understanding of social integration and consequent resettlement approaches, policies, and programs for those in limbo.

The significant personal and national costs of leaving refugees in limbo is the subject of a study by Tim Coates and Caitlin Hayward. They review various barriers to inte- 
gration of those refugees in legal limbo in Canada. Personal costs related to integration, education, family separation, mental health, and travel are highlighted. The authors also document the monetary costs to the welfare system, labour markets, and the medical system of people who cannot get on with their lives. They also demonstrate that there is very likely over \$334 million dollars in lost earnings among this population. While pointing to the need for further research, they are able to already conclude that leaving refugees in limbo is a huge cost to Canada.

Andrew Brouwer, in turn, makes a careful legal argument for how Canada's current policy could be amended to end limbo for those who are protected persons, but who have not yet been granted permanent resident status. The article details the barriers faced by refugees in this situation, barriers which range from the inability to unite with family to difficulties acquiring employment. Then, drawing on opportunities in, and arguments from, current Canadian law, as well as from international law, Brouwer reasons that the current policy is neither necessary nor just, and is counterproductive to the integration of those seeking a safe home in Canada. He thus proposes that Canada dispense with a redundant second screening and automatically grant permanent residence to those determined to be protected persons.

The final article in this issue does not directly discuss refugees in legal limbo... but examines what is perhaps limbo of a different kind. The authors, Kevin Pottie, Judith Belle Brown, and Samuel Dunn, present a powerful and moving study of the emotional stress of Central American men resettling in Canada. It is a reminder of the very personal and painful impact of being forced to leave one's home and to try to create a new home and find a new sense of belonging.

Betwixt and between - this is the nature of the limbo experienced by refugees and stateless persons the world over. As one of the refugees in Humpage and Marston's article, states: "Once we got to Australia we thought we would be safe and protected... and then we got this temporary protection visa, we thought we were slowly dying again because we started a new form of suffering." Or as a Somali refugee interviewed by Awa M. Abdi in a camp in Kenya goes so far as to contemplate, "The other conflict [remaining in Somalia] might have been better; at least we could get out, we could move around even if a bullet hits you. And now we miss that. ... now we cannot move around. You just sit around."

A new sense of belonging, a new sense of home for those in limbo will require changes to, and implementation of, both domestic and international policy, law, and practice. Recognition of the personal and economic costs of leaving people in limbo will require mindfulness to justice in ensuring that refugees and stateless persons truly have the opportunity to create a new life.

Harry J. Kits has been Executive Director of Citizens for Public Justice since 1988. Citizens for Public Justice undertakes Canadian public policy advocacy based on its understanding of the biblical call to justice and mercy. Harry Kits has been involved in the organization's policy work on issues ranging from child poverty to aboriginal rights to refugees in limbo. Most recently he has spearheaded efforts to ensure that refugees in limbo in Canada are able to access government loan programs in order to attend university and college.

(C) Harry J. Kits, 2005. This open-access work is licensed under a Creative Commons Attribution-NonCommercial 4.0 International License, which permits use, reproduction and distribution in any medium for non-commercial purposes, provided the original author(s) are credited and the original publication in Refuge: Canada's Journal on Refugees is cited. 